\title{
UNRAVELING PHYSIOLOGICAL TRAITS OF Jatropha curcas, A BIODIESEL PLANT, TO OVERCOME SALINITY CONDITIONS ${ }^{1}$
}

\author{
YURI LIMA MELO ${ }^{2}$, ROSA RODÉS GARCIA ${ }^{3}$, CRISTIANE ELIZABETH COSTA DE MACÊDO ${ }^{4}$, EDUARDO \\ ALFONSO ORTEGA DELGADO ${ }^{3}$, JOSEMIR MOURA MAIA ${ }^{5}$, PATRICIA ORTEGA-RODÉS ${ }^{3 *}$
}

\begin{abstract}
Dry land systems spread all over the world and comprise $41.3 \%$ of the terrestrial area, which host $34.7 \%$ of the global population, so it is convenient to propose crops able to grow there. Jatropha curcas is a plant adapted to arid and semiarid regions as well as sub-humid conditions, being a potential source of biodiesel. The challenge is to understand the physiology of $J$. curcas, which enables it to live under saline and drought conditions. The seeds of $J$. curcas used came from Ciego de Ávila Province, Cuba. Seven-day-old seedlings were cultivated in $1.5 \mathrm{~L}$ pots with half strength Hoagland solution for 42 days under semi-controlled conditions. $\mathrm{NaCl}$ added to solutions in pots provided 75 or $150 \mathrm{mM}$ treatments for $240 \mathrm{~h}$ before measurements. Leaf growth, net photosynthesis and stomatal pore area were affected by $150 \mathrm{mM} \mathrm{NaCl}$. Non-photochemical quenching of leaves was only changed by $150 \mathrm{mM} \mathrm{NaCl}$ after $24 \mathrm{~h}$; the electron transport rate had a tendency to decrease in leaves under saline conditions. The gene expression pattern changed for SOS1 and HKT1 according to the $\mathrm{NaCl}$ used in the medium, indicating active mechanism to deal with $\mathrm{Na}^{+}$in the cell. In general, Cuban $J$. curcas plants were able to grow and perform photosynthesis under $75 \mathrm{mM} \mathrm{NaCl}$, which represents 7 $\mathrm{dS} \mathrm{m}{ }^{-1}$, a condition that restricts growth for many plant species.
\end{abstract}

Keywords: Physic nuts. Salt stress. Gas exchange. SOS1. HKT1.

\section{DESVENDANDO TRAÇOS FISIOLÓGICOS DE Jatropha curcas, PLANTA MATRIZ DO BIODIESEL, PARA SUPERAR CONDIÇÕES DE SALINIDADE}

\begin{abstract}
RESUMO - Os sistemas de terras secas se espalham por todo o mundo e compreendem $41,3 \%$ da área terrestre, que hospeda $34,7 \%$ da população global; é conveniente propor culturas capazes de crescer nessas áreas. Jatropha curcas é uma planta adaptada às regiões áridas e semiáridas, bem como às condições subúmidas; é uma fonte potencial de biodiesel. O desafio é entender a fisiologia da $J$. curcas que lhe permite viver em condições salinas e secas. As sementes de $J$. curcas utilizadas são provenientes da província de Ciego de Ávila, Cuba. Plântulas de sete dias em vasos de 1,5 L com solução Hoagland de meia força foram cultivadas durante 42 dias em condições semi-controladas. $\mathrm{O} \mathrm{NaCl}$ adicionado às soluções em vasos forneceu tratamentos de 75 ou $150 \mathrm{mM}$ por $240 \mathrm{~h}$ antes das avaliações. O crescimento foliar, a fotossíntese líquida e a área de poros estomáticos foram afetados pelo $\mathrm{NaCl} 150 \mathrm{mM}$. O quenching não fotoquímico das folhas foi alterado apenas por $\mathrm{NaCl} 150 \mathrm{mM}$ após $24 \mathrm{~h}$; a taxa de transporte de elétrons teve uma tendência a diminuir nas folhas em condições salinas. O padrão de expressão gênica mudou para SOS1 e HKT1 de acordo com o NaCl usado no meio, indicando mecanismo ativo para lidar com $\mathrm{Na}^{+}$na célula. Em geral, as plantas de $J$. curcas de Cuba conseguiram crescer e realizar fotossíntese sob $\mathrm{NaCl} 75 \mathrm{mM}$, o que representa $7 \mathrm{dS} \mathrm{m}^{-1}$, uma condição que restringe o crescimento para muitas espécies de plantas.
\end{abstract}

Palavras-chave: Pinhão-manso. Estresse salino. Trocas gasosas. SOS1. HKT1.

\footnotetext{
${ }^{*}$ Corresponding author

${ }^{1}$ Received for publication in 10/02/2019; accepted in 03/02/2020.

Paper extract from the project CAPES/MES Cuba 141/2011

${ }^{2}$ Universidade Federal Rural do Semi-Árido, Mossoró, RN, Brazil; yurimelo86@gmail.com - ORCID: 0000-0003-2171-3168.

${ }^{3}$ Universidad de La Habana, Habana, Cuba; rrodes@fq.uh.cu - ORCID: 0000-0001-6176-212X, eortega@fq.uh.cu - ORCID: 0000-0003-

4176-7171,portega@fq.uh.cu-ORCID: 0000-0003-1532-9231.

${ }^{4}$ Universidade Federal do Rio Grande do Norte, Natal, RN, Brazil; cristianemacedo@ufrnet.br - ORCID: 0000-0002-5844-0848.

${ }^{5}$ Universidade Estadual da Paraíba, Catolé do Rocha, PB, Brazil; jmouram@gmail.com - ORCID: 0000-0002-2391-0838.
} 


\section{INTRODUCTION}

It is estimated that approximately $20 \%$ of the cultivated land in the world and almost half of all irrigated land is affected by salinity (SHIRIVASTAVA; KUMAR, 2015). Soil salinity is a serious environmental problem especially in arid and semiarid areas (ALLBED; KUMAR, 2013), where evapotranspiration rate generally exceeds rainfall. Salt stress interferes with plant growth, changing metabolic, physiological and anatomical features, which contributes to the reduction of crop yield and causes enormous economic losses. High concentrations of $\mathrm{Na}^{+}$and $\mathrm{Cl}^{-}$ions in leaves could affect the stomatal and non-stomatal components of photosynthesis. The accumulation of intracellular $\mathrm{Na}^{+}$during salt stress conditions could change the $\mathrm{K}^{+} / \mathrm{Na}^{+}$ratio, which seems to affect the photosynthetic process (BRUGNOLI; BJÖRKMAN, 1992).

Under environmental conditions that are unfavorable for the photosynthetic fixation of $\mathrm{CO}_{2}$, an excess of light energy absorbed by photosynthetic pigments accelerates photoinhibition; however, plants exhibit different strategies to protect themselves against photoinhibition and photosynthetic damage (TAKAHASHI; BADGER, 2011).

Jatropha curcas L. has been considered a promising agro-energy crop, mainly because it is a very resistant oilseed plant that grows naturally in non-cultivable areas and is often exposed to drought conditions (SAPETA et al., 2013), heavy metals (RAJ; MOHAN, 2016), high temperatures (SILVA et al., 2018) and salinity (DÍAZ-LÓPEZ et al., 2012). For this reason, the survival capacity of $J$. curcas L. plants to abiotic stress has been the subject of previous studies. Despite these studies, there have been few reports on the photosynthetic responses of $J$. curcas L. plant to salinity. In the present study, we analyzed the photosynthetic and respiratory metabolism of $J$. curcas L. exposed to salt stress conditions.

The quantification of gas exchange alone is not enough to conclude about the effect of salinity on the physiological response of a plant. However, if it is combined with other parameters like growth, membrane damage, electron flux and gene expression, all together could be a good tool to quantify the tolerance to different stress conditions. In addition, the capacity of some plants to modify the expression of genes involved in cell homeostasis, especially those including SOS family of $\mathrm{Na}^{+} / \mathrm{H}^{+}$ exchangers and HKT, a $\mathrm{Na}^{+}$transporter, has been a key step to understanding the salt tolerance process.
Modification of the expression pattern of SOS genes was analyzed in this work.

\section{MATERIALS AND METHODS}

\section{Plant growth conditions}

Seeds of $J$. curcas L. plants growing wild in the eastern-central region of Cuba (Ciego de Ávila province) were previously selected by size $(2 \pm 0.1$ $\mathrm{cm}$ large) and were surface disinfected using commercial hypochlorite $(0.5 \%, \mathrm{~V} / \mathrm{V})$ for $5 \mathrm{~min}$. The disinfectant was removed by at least five washings with sterile distilled water for at least $1 \mathrm{~min}$ each.

Seeds germinated in paper towel roll system with a ratio of $1.5 \mathrm{~mL}$ of water per gram of paper. Seedlings of about 7 days old were transferred to 1.5 L pots containing Hoagland nutrient solution (HOAGLAND; ARNON, 1950), half strength, $\mathrm{pH}$ 6.0 , where air was pumped to provide the required conditions for the respiration of the root system. The hydroponic cultivation was set under semi-controlled conditions (temperature: $28 \pm 1.5{ }^{\circ} \mathrm{C}$, illumination: $100 \mu \mathrm{mol}$ photons $\mathrm{m}^{-2} \mathrm{~s}^{-1}, 65 \% \mathrm{RH}, 12 \mathrm{~h}$ light $/ 12 \mathrm{~h}$ dark cycle).

Stress conditions were applied to 42-day-old plants. Two sets of plants stayed in half-strength Hoagland nutrient solution supplied with 75 or 150 $\mathrm{mM} \mathrm{NaCl}$ for 10 days. One set of plants remained in half-strength Hoagland nutrient solution as control.

\section{Growth rate and membrane damage}

Relative Leaf Growth Rates (RLGR) and Absolute Leaf Growth Rates (ALGR) were determined by non-destructive analyses, using the equations: RLGR $\left[\mathrm{cm}^{2} \mathrm{~cm}^{-2} \mathrm{day}^{-1}\right]=\left(\operatorname{Ln~} \mathrm{A}_{2}-\mathrm{Ln}\right.$ $\left.\mathrm{A}_{1}\right) /\left(\mathrm{t}_{2}-\mathrm{t}_{1}\right)$; ALGR $\left[\mathrm{cm}^{2}\right.$ day $\left.^{-1}\right]=\left(\mathrm{A}_{2}-\mathrm{A}_{1}\right) /\left(\mathrm{t}_{2}-\mathrm{t}_{1}\right)$ according to Hunt (1990); $A_{2}$ represents the leaf area at $t_{2}$ and $A_{1}$ the leaf area at $t_{1}$. Pictures of the leaf were taken with a commercial camera (Canon EOS $700 \mathrm{D}, 5184 \times 3456$ ) using a cardboard with scale as background for each leaf. The leaf area was determined using the images of all leaves and analyzed by ImageJ software (version 1.45).

The relative water content (RWC) was determined following Irigoyen, Emerich and Sanchez-Diaz (1992), calculated as RWC = (fresh weight - dry weight)/(turgid weight - dry weight). The complete leaf was weighed immediately after harvesting to obtain the fresh weight $(\mathrm{FW})$. The same tissues were placed in water at $25{ }^{\circ} \mathrm{C}$ for $6 \mathrm{~h}$, followed by weighing, and the turgid weights were calculated. The samples were dried in an oven at $75^{\circ}$ 
C until constant weight to obtain dry weights.

Ion leakage, an indirect method for assessing damage to cell membrane was used. The selected leaves or roots were washed with water. The leaf was cut into discs of $2.5 \mathrm{~cm}$ diameter and the roots were cut into pieces of similar size and transferred to 100 $\mathrm{mL}$ flasks containing $25 \mathrm{~mL}$ of bidistilled sterile water at $25{ }^{\circ} \mathrm{C}$. The flask was shaken on a gyratory shaker at $250 \mathrm{rpm}$ for $4 \mathrm{~h}$ at RT. After incubation, initial electrical conductivity (Ci) was measured using a Hanna HI8633 conductivity meter. To obtain a reference value for the conductivity, the samples were boiled for $5 \mathrm{~min}$ and the final electrical conductivity $(\mathrm{Cf})$ was measured. The leaf ion leakage was calculated as $(\mathrm{Ci} / \mathrm{Cf}) * 100$ (GULEN; ERIS, 2004).

\section{Gas exchange and chlorophyll fluorescence}

To determine the quantity of stomata and stomatal opening, the methodology described by impressions and collection, with a clear tape, of the epidermal surface was applied (SLAVIK, 1974). Epidermal impressions of the abaxial and adaxial surfaces of leaves were taken. Samples were observed and photographed under an Olympus BX40 optical microscope, coupled to a DP-70 camera using Stream Essentials software (v1.6.1.).

The photosynthetic and respiratory activity of plants was determined in the youngest fullyexpanded leaves attached to the plants (about 52 days old) using an open-system infrared gas analyzer (IRGA) (Qubit Systems Inc., Canada) with $200 \mathrm{~mL}$ $\min ^{-1}$ air flux. Photosynthetic activity was measured at saturating light intensity of $620 \mu \mathrm{mol} \mathrm{m} \mathrm{m}^{-2} \mathrm{~s}^{-1}$ (PAR). Respiration measurements were done in the dark. Chlorophyll fluorescence was measured using modulated light fluorimeter (MINI-PAM) (Walz, Germany). Basic (background) chlorophyll fluorescence (Fo), maximal chlorophyll fluorescence (Fm), maximum quantum yield of PS II ( $\mathrm{Fv} / \mathrm{Fm})$, PSII efficiency in light (Fv'/Fm'), photochemical quenching ( $\mathrm{qP}$ ), non-photochemical quenching (qN) and relative electron transport rate (ETR) were quantified.

The leaves were previously adapted to the dark for 30 minutes, enabling all PS II reaction centers and electron carriers of the PS II acceptor side to be re-oxidized. Fo was obtained with low intensity modulated light $\left(<0.1 \mathrm{mmol} \mathrm{m} \mathrm{m}^{-2} \mathrm{~s}^{-1}\right)$ to avoid any effect on the variable fluorescence. Fm was obtained by 0.6 pulses of saturating light at $10000 \mu \mathrm{mol} \mathrm{m} \mathrm{m}^{-2} \mathrm{~s}^{-1}$. Fv was calculated from the difference Fm-Fo. Fm', Fv' and $\mathrm{Fo}^{\prime}$ values were obtained in the above samples with application of actinic light of $190 \mu \mathrm{mol} \mathrm{m} \mathrm{m}^{-2} \mathrm{~s}^{-1}$ and pulses of saturating light at $10000 \mu \mathrm{mol} \mathrm{m} \mathrm{m}^{-2} \mathrm{~s}^{-1}$. The air temperature and humidity during the experiment was about $28{ }^{\circ} \mathrm{C}$ and $59 \%$, respectively.

\section{RNA Isolation and Quantification by RT-PCR}

Total RNA was isolated using a Plant RNA Kit (Analytic Jena, Jena, Germany). Equal loading of RNA was visualized by EtBr stained rRNA. Aliquots of $2 \mu \mathrm{g}$ RNA were treated with DNaseI prior to the reverse transcription reaction using RevertAidTM Reverse Transcriptase (Fermentas, Life Sciences) with Oligo(dT) 18 .

For semi-quantitative RT-PCR an equal concentration of cDNA (relative to JcActin, a housekeeping gene) was used for specific primer amplification. cDNA products were amplified with 0.5 unit of Dream Taq Green Polymerase (Fermentas) in the buffer provided by the manufacturer, which contains $\mathrm{MgCl}_{2}$, in the presence of the specific oligonucleotides and dNTPs. Reactions were carried out in the T3Thermocycler PCR system. A first denaturation step of 5 min at 95 ${ }^{\circ} \mathrm{C}$ was followed by a number of specific cycles of $30 \mathrm{~s}$ at $95{ }^{\circ} \mathrm{C}, 30 \mathrm{~s}$ at specific annealing temperature (according to the primer) and $30 \mathrm{~s}$ at $72{ }^{\circ} \mathrm{C}$, followed by a final extension for $5 \mathrm{~min}$ at $72{ }^{\circ} \mathrm{C}$.

Primers were designed using Perl primer (http://perlprimer.sourceforge.net/download.html).

The primer sequences used were 5'CTCTCATTGGAAGCTG 3' (Forward primer, F) and 5'CACCTGTAGAACTTAGAAGCAC 3' (Reverse primer, R) for JcActin; 5'GATTTGAGAGCACTTGTTTCAG 3' (F) and 5'TCCCAGGTTCTTCCTTACAG 3' (R) for Jc SOS1; 5'GCCTTTGAGATGATTACCCT 3' (F) and 5'GCAACTTCATAGACCTCCAG 3' (R) for Jc SOS2; 5'CGATCTCTGTCTATCTTCCACC 3' (F) and 5'TCAAGGATGGATTACGAGTCAC 3' (R) for JC SOS3; 5'TGATGATGTATCTTCCACCA 3', (F) and 5'TAGCCTTCCAAAGAACATGAC 3' (R) for JC_HKT1.

\section{Statistical analysis}

The data met the criteria of normal distribution (chi-square) and homogeneity of variances (Levene Test) and were analyzed by parametric tests. The type of analysis of variance (ANOVA) used depended on the experimental design. One-way ANOVA was used to analyze designs with a single categorical independent variable (factor) and factorial ANOVA was used to analyze the higher order interactive effects of multiple categorical independent variables. The Range test (multi-stage) was performed using Tukey tests. When the results of statistical analysis were similar for $\alpha=0.05$ and $\alpha=0.01$, only difference for $\alpha=0.01$ is informed; if they were different, only $\alpha=$ 0.05 is informed. Data analysis was conducted using STATISTICA (data analysis software system), version 7 (www.statsoft.com) (StatSoft, Inc., 2004). 


\section{RESULTS AND DISCUSSION}

\section{Membrane damage}

The cell membrane of roots was affected within the first $6 \mathrm{~h}$ of 75 and $150 \mathrm{mM} \mathrm{NaCl}$ treatment (Figure 1). Although differences in the percentage of ion leakage from stress treatments relative to control increased further after $240 \mathrm{~h}$, the mean values of the percentage of electrolyte leakage decreased compared to the first $6 \mathrm{~h}$ of stress. Ion leakage in the leaf was not affected (data not shown).

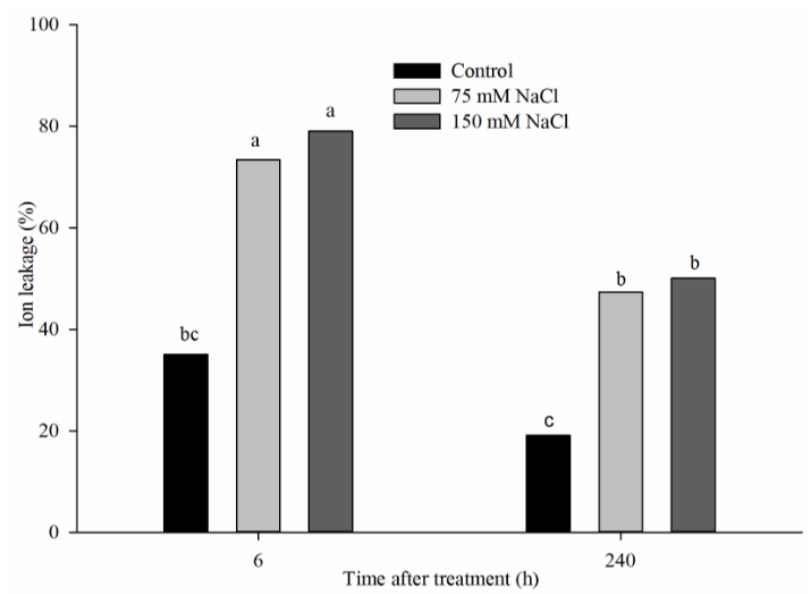

Figure 1. Ion leakage of roots of $J$. curcas L. plants after 6 and $240 \mathrm{~h}$ of salt stress conditions. Different letters denote significant difference between samples by Tukey test; $\mathrm{P}<0.05 ; \mathrm{n}=5 ; \mathrm{SMD}=19.36$.

Electrolyte leakage is an important permeability index of the cell membrane. In the present study, the increase in electrolyte leakage suggests increases in membrane permeability, possibly due to the intensification of lipid peroxidation, common in plants subjected to salinity (JIANG et al., 2017). Nevertheless, an apoplastic accumulation of ions in salt-stressed samples will contribute to electrolyte leakage although they are not involved in cellular efflux. In any of the cases, the decrease of ion leakage as stress time increased could be an indication of less damage or less ion accumulation in the apoplast. This is evidence that some tolerant mechanism is functioning.

\section{Plant growth and water content}

The rates of leaf growth, represented by RLGR and ALGR, decreased after $240 \mathrm{~h}$ of exposure to salt stress in the treatment with $150 \mathrm{mM} \mathrm{NaCl}$ (Table 1).

Table 1. Relative Leaf Growth Rate (RLGR) and Absolute Leaf Growth Rate (ALGR) after $240 \mathrm{~h}$ of $J$. curcas L. plants growing under salt stress. Different letters denote significant difference between treatments by Tukey test; $\mathrm{P}<0.05 ; \mathrm{n}=11$.

\begin{tabular}{ccc}
\hline $\begin{array}{c}\text { Treatments } \\
(\mathrm{mM} \mathrm{NaCl})\end{array}$ & $\begin{array}{c}\text { RLGR } \\
\left(\mathrm{cm}^{2} \mathrm{~cm}^{-2} \mathrm{day}^{-1}\right)\end{array}$ & $\begin{array}{c}\text { ALGR } \\
\left(\mathrm{cm}^{2} \mathrm{day}^{-1}\right)\end{array}$ \\
\hline 0 & $0.015 \mathrm{a}$ & $4.218 \mathrm{a}$ \\
75 & $0.007 \mathrm{ab}$ & $1.545 \mathrm{ab}$ \\
150 & $-0.020 \mathrm{~b}$ & $-3.736 \mathrm{~b}$ \\
\hline SMD & 0.022 & 5.437 \\
\hline
\end{tabular}

The ALGR and RLGR of $J$. curcas L. leaves under salt treatment of $75 \mathrm{mM} \mathrm{NaCl}$ showed a similar response to those found in the control, indicating an acclimation to the saline conditions after $240 \mathrm{~h}$. The reduction of ALGR and RLGR in plants growing under $150 \mathrm{mM}$ of $\mathrm{NaCl}$ compared to control can be associated with senescence and leaf abscission processes. These two processes are caused by an excess of toxic ions such as $\mathrm{Na}^{+}$and $\mathrm{Cl}^{-}$ (MUNNS, 2002). Díaz-López et al. (2012) reported an increase of $\mathrm{Na}^{+}$and $\mathrm{Cl}^{-}$in the leaves and roots of
$J$. curcas L. growing under saline conditions for 40 days.

The presence of $\mathrm{NaCl}$ in the nutrient solution reduced the RWC in leaves of $J$. curcas for all exposure times under the highest salinity condition (150 $\mathrm{mM} \mathrm{NaCl}$ ), with significant differences compared to the control treatment level. Relative water content of plants with $\mathrm{NaCl}$ concentrations of $75 \mathrm{mM}$ did not differ from those of the control and were different only from the higher salinity treatment at $24 \mathrm{~h}$ (Figure 2). 


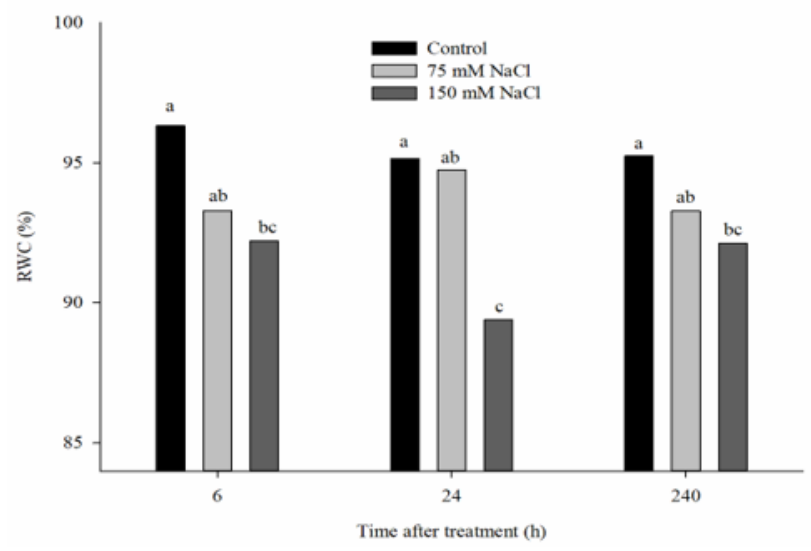

Figure 2. Relative water content (RWC) of $J$. curcas L. plants after 6, 24 and $240 \mathrm{~h}$ of salt treatments $(75$ and $150 \mathrm{mM}$ $\mathrm{NaCl}$ ). Different letters denote significant difference between samples by Tukey test; $\mathrm{P}<0.05 ; \mathrm{n}=11 ; \mathrm{SMD}=3.40$.

The lowest RWC values were obtained in the treatment of $150 \mathrm{mM}$. The reduction in RWC compared to control was not extremely strong because it remained between $93.33 \%$ and $89.39 \%$; nevertheless, it could have an influence on plant growth and other physiological processes. The rate of irreversible cell volume increase is proportional to the rates of water uptake by the expanding cell. Thus, plant cell expansion depends on turgor pressure in a direct manner as well as on biochemical processes acting on the wall structure, such as increase in the activity of specific enzymes (MOORE et al. 2008). According to Rad et al. (2013), the RWC can be used as parameter to identify tolerant genotypes with high yield. In our case the lowest value of RWC $(89.39 \%)$ obtained under the highest salinity stress $(150 \mathrm{mM} \mathrm{NaCl})$ is considered according to Moore et al. (2008) a mild degree of water deficit. Other effects of water deficit are modification in the synthesis and transport of growth regulators, stomatal behavior, respiration, photosynthesis, nutrient uptake, among others (BRADFORD; HSIAO, 1982). The presence of $\mathrm{NaCl}$ in the nutrient solution reduced the RWC of $J$. curcas L. leaf after $6 \mathrm{~h}$ of salt treatment $(75 \mathrm{mM}$ $\mathrm{NaCl}$ ) and after 6 and $24 \mathrm{~h}$ of $150 \mathrm{mM} \mathrm{NaCl}$ (Figure 2 ). The soil-root osmotic gradient is the main force responsible for water absorption by the plant. In saline soil the osmotic contribution to water retention is high, causing reduced water availability, hence reducing the absorption of water by the roots. Negative correlation between total water uptake and salinity has been reported by Pessarakli, Huber and tucker (1989). Under salt stress the plant root permeability (expressed as hydraulic conductivity of the root system) decreased significantly. This may explain the reduction in water absorption rate under salt stress conditions.

The cells appear turgid in control plants and even in the $75 \mathrm{mM} \mathrm{NaCl}$ treatment; in $150 \mathrm{mM} \mathrm{NaCl}$ treatment cells appear like wrinkled cells, especially observed after $24 \mathrm{~h}$ (Figure 3).
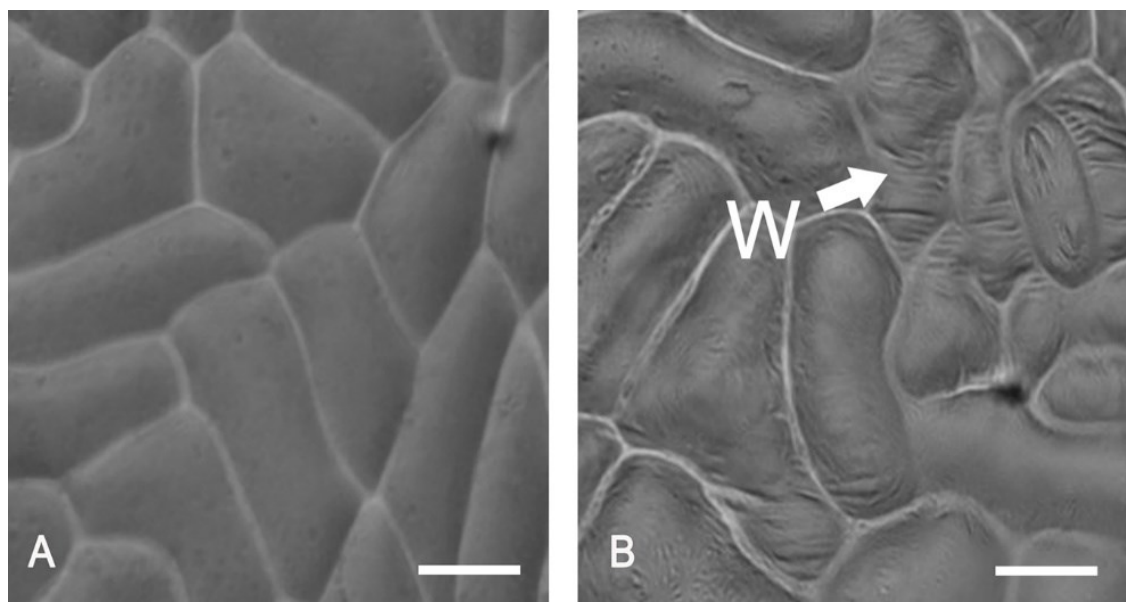

Figure 3. Photograph of epidermal impressions of $J$. curcas L. plants under control (A), and $150 \mathrm{mM} \mathrm{NaCl}$ after $24 \mathrm{~h}$ (B). W: wrinkled cells. Bar: $20 \mu \mathrm{m}$. The images were taken by Optic Olympus BX-40 Microscope using an Olympus DP-72 camera. 
Possibly, the loss of cellular turgor observed in leaf epidermal cells of plants exposed to $150 \mathrm{mM}$ $\mathrm{NaCl}$ during the first $24 \mathrm{~h}$ may also be associated with a reduction in RWC because this phenomenon is directly related to the declining availability of water, which leads to a loss of cell turgor. It is made clear with the appearance of wrinkled cells (W) observed in the leaves of $J$. curcas L. plants after 24 $\mathrm{h}$ of saline treatment (Figure $3 \mathrm{~B}$ ).

The low variations in the RWC of Jatropha curcas L., under $75 \mathrm{mM} \mathrm{NaCl}$, corroborate studies by Díaz-López et al. (2012) that prove the species' moderate tolerance to salinity of up to $90 \mathrm{mM} \mathrm{NaCl}$. The authors also suggest that the effects of ionic stress prevail over the effects of the physiological drought of salt stress, as evidenced by the low variation of RWC in the same study.

According to Wang and Nii (2015), the leaf area did not increase during the period of salinity stress in Amaranthus plants. However, salinity caused a reduction in the volume of epidermal cells in $J$. curcas leaves, especially in plants receiving the treatment of $150 \mathrm{mM} \mathrm{NaCl}$ after 24 hours of exposure (Figure $3 \mathrm{~B}$ ). This volume reduction could be due to a reduction in cell turgor pressure, provoked by the osmotic effect of $\mathrm{NaCl}$ in the growing medium. This effect probably has a direct influence on the reduction of leaf growth rate, since the plant growth is the consequence of cell division and cell elongation. As leaves lose water, the cellular turgor pressure decreases and the cell membrane separates from the cell wall. After a critical point, the cell deformity results in a shrinkage of the leaf (KRAMER; BOYER, 1995) provoking leaf area reduction. Leaf initiation, which is governed by cell division, was shown to be unaffected by salt stress in sugar beet, but leaf extension was found to be a salt- sensitive process (BATOOL; SHAHZAD; NOSHIN, 2014). At the plant level, leaf expansion is one of the most sensitive processes to water stress (BOYER, 1970), one of the consequences of salt stress. Tardieu, Granier and Muller (2011) proposed a network of coordination for processes involved in the decrease of growth with water deficit. Three essentially independent macroscopic processes are affected in parallel, biomass accumulation, cell division and expansive growth, without central coordination with feedback between them.

A reduction in leaf area can be related to a strategy to decrease transpiration and thus to conserve the available water. Reduced leaf area is probably the more obvious mechanism by which the plants restrict the water loss in response to drought (CONNOR; JONES, 1985). However, the lower RLGR and ALGR values obtained after $240 \mathrm{~h}$ could be a result of the lower photosynthesis, influencing the growth of the plant. It may have been influenced by the limitation of $\mathrm{CO}_{2}$ assimilation that occurs in plants under this condition.

\section{Gas exchange}

Net photosynthesis decreased significantly in the leaves of plants growing under the salt conditions of $150 \mathrm{mM} \mathrm{NaCl}$ after $6 \mathrm{~h}$ of exposure and did not recover after $240 \mathrm{~h}$ (Figure 4). The photosynthesis in plants maintained at $75 \mathrm{mM} \mathrm{NaCl}$ concentration was similar to that of control plants for the three exposure times. Respiratory activity was lower in plants in the presence of $\mathrm{NaCl} 75$ and $150 \mathrm{mM} \mathrm{NaCl}$ relative to the control for the first 6 hours, but maintained similar values to those of control plants after 24 and $240 \mathrm{~h}$ (Figure 4).
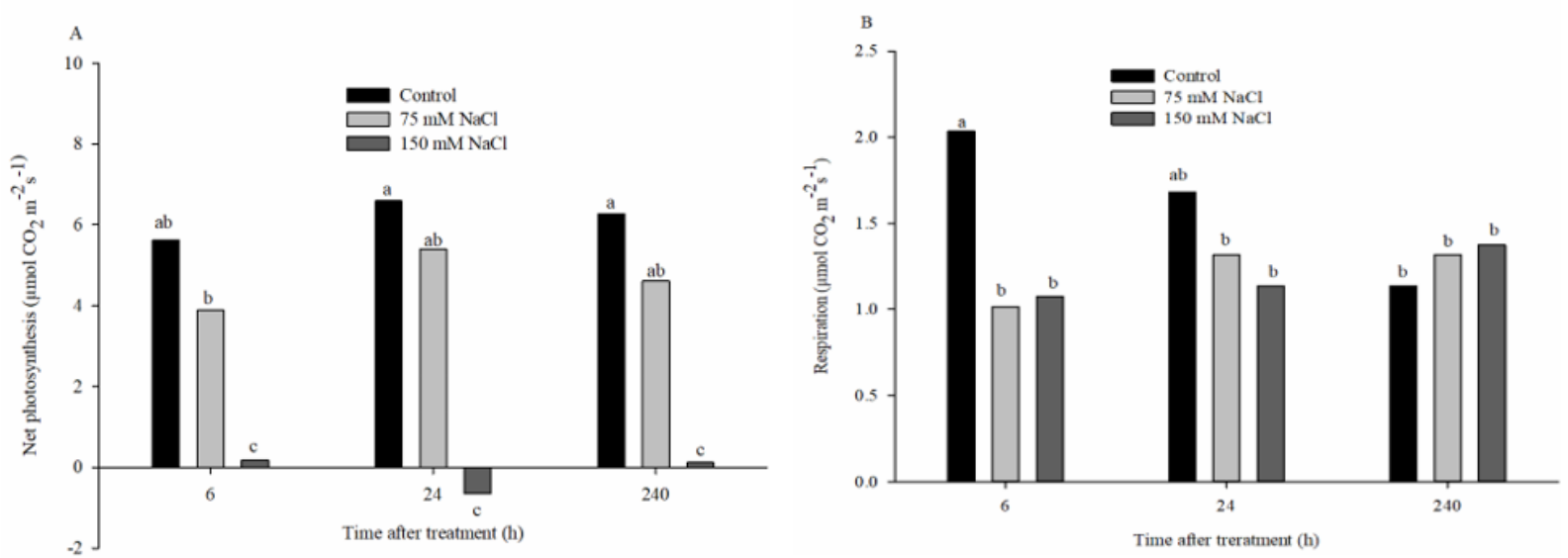

Figure 4: Net photosynthesis (A) and respiratory activity (B) of $J$. curcas L. leaf under salt stress conditions (75 and 150 $\mathrm{mM} \mathrm{NaCl})$. Different letters denote significant difference between samples by Tukey test; $\mathrm{P}<0.05, \mathrm{n}=5 ; \mathrm{SMD}=2.21(\mathrm{~A})$; $\mathrm{SMD}=0.65(\mathrm{~B})$. 
The extreme photosynthetic dysfunction observed in plants under $150 \mathrm{mM} \mathrm{NaCl}$ can be induced by different causes at different levels: a low capacity of photochemical reactions that lead to loss of efficiency in the transformation of light energy, a low $\mathrm{CO}_{2}$ diffusion into the intercellular spaces due to decrease in the size of stomatal opening, or limitations by metabolism inhibition in biochemical reactions, among others.

After prolonged periods of low photosynthesis, starch turnover mechanism (STITT; ZEEMAN, 2012) could operate to maintain the growth and respiration in $J$. curcas L. plants under $150 \mathrm{mM}$ of $\mathrm{NaCl}$ treatment.

The net photosynthesis in $J$. curcas L. plants subjected to $75 \mathrm{mM} \mathrm{NaCl}$ (Figure 4B) did not show significant difference relative to control for any of the evaluated times. This indicates that $75 \mathrm{mM} \mathrm{NaCl}$ concentration could be considered a moderate salinity condition for this plant. $J$. curcas L. may be an appropriate species for the semi-arid regions where the availability of water in the soil and in the air is low.

The inhibition of photosynthesis during salinity could be related to a reduction in $\mathrm{CO}_{2}$ exchange rate. It can affect the diffusion of $\mathrm{CO}_{2}$ to the chloroplast by changes in mesophyll structure, which decreases the conductance to $\mathrm{CO}_{2}$ diffusion within the leaf, as suggested by Delfine et al. (1999). $\mathrm{CO}_{2}$ exchange depends on the stomatal opening degree and intracellular resistance in moving it from the intercellular air spaces to the carboxylation sites. Decrease in photosynthetic process due to the intracellular resistance depends on the species but, according to Mederski, Chen and Curry (1975), it is little or no affected when the RWC is within the range of $60 \%-70 \%$ in soybean plant. Thus, the decrease in photosynthetic process obtained in this work seems to be more related to stomatal than to nonstomatal regulation.

On the other hand, many enzymes involved in carbon metabolism are susceptible to salt stress. Miteva, Zhelev and Popova (1992) suggested that, in barley plants, $\mathrm{NaCl}$ salinity inhibited the synthesis of total soluble protein with a more pronounced synthesis inhibition of Ribulose-1,5-bisphosphate carboxylase/oxygenase (RuBisCO, EC 4.1.1.39), the key enzyme in the photosynthetic carbon reduction. The level and the carboxylating capacity of RuBisCO decreases in plants subjected to salt stress, reducing the photosynthetic capacity regardless of stomatal closure in Phaseolus vulgaris (SEEMANN; SHARKEY, 1986). The reduction in the amount of RuBisCO protein under salt stress might imply modification at different levels from transcription to post-translation level. Salt stress led to several photosynthesis-related (ATP synthesis coupled to proton transport, light reaction and xanthophyll cycle) gene down-regulation (CHAVES; FLEXAS; PINHEIRO, 2009). According to Lawlor (2002), one of the most important factors which regulate photosynthesis under salt stress is the inhibition of ATP synthesis, which limits the synthesis of ribulose bisphosphate.

Plants under various stress conditions may be affected in their photochemical reactions. (Table 2) shows the results obtained by studying some chlorophyll fluorescence components of J. curcas L. under salt stress.

Table 2. Variation of chlorophyll fluorescence components in $J$. curcas L. leaf during salt stress, compared to the Control without salt. Fv/Fm: maximum quantum yield of PS II; Fv'/Fm': PSII efficiency in light; qP: photochemical quenching; qN: non-photochemical quenching; ETR: electron transport rate $\left(\mu \mathrm{mol}\right.$ electrons $\left.\mathrm{m}^{-2} \mathrm{~s}^{-1}\right)$. Different letters in each column denote significant difference between samples by Tukey test; $\mathrm{P}<0.05 ; \mathrm{n}=5 ; \mathrm{ns}$ : non-significant difference.

\begin{tabular}{ccccccc}
\hline Time of stress (h) & $\begin{array}{c}\text { Treatments } \\
(\mathrm{mM} \mathrm{NaCl})\end{array}$ & Fv/Fm & $\mathrm{Fv}^{\prime} / \mathrm{Fm}^{\prime}$ & $\mathrm{qP}$ & $\mathrm{qN}$ & ETR \\
\hline \multirow{2}{*}{6} & 0 & $0.80 \mathrm{~ns}$ & $0.43 \mathrm{a}$ & $0.57 \mathrm{a}$ & $0.17 \mathrm{ab}$ & $34.13 \mathrm{a}$ \\
& 75 & $0.81 \mathrm{~ns}$ & $0.44 \mathrm{a}$ & $0.58 \mathrm{a}$ & $0.09 \mathrm{~b}$ & $35.43 \mathrm{a}$ \\
& 150 & $0.81 \mathrm{~ns}$ & $0.38 \mathrm{ab}$ & $0.51 \mathrm{a}$ & $0.11 \mathrm{~b}$ & $30.07 \mathrm{ab}$ \\
\hline \multirow{2}{*}{24} & 0 & $0.79 \mathrm{~ns}$ & $0.34 \mathrm{ab}$ & $0.45 \mathrm{~b}$ & $0.11 \mathrm{~b}$ & $27.00 \mathrm{~b}$ \\
& 75 & $0.80 \mathrm{~ns}$ & $0.25 \mathrm{~b}$ & $0.36 \mathrm{~b}$ & $0.23 \mathrm{ab}$ & $20.23 \mathrm{c}$ \\
& 150 & $0.80 \mathrm{~ns}$ & $0.24 \mathrm{~b}$ & $0.37 \mathrm{~b}$ & $0.33 \mathrm{a}$ & $19.80 \mathrm{c}$ \\
\hline \multirow{2}{*}{240} & 0 & $0.80 \mathrm{~ns}$ & $0.31 \mathrm{ab}$ & $0.43 \mathrm{~b}$ & $0.18 \mathrm{ab}$ & $24.57 \mathrm{bc}$ \\
& 75 & $0.80 \mathrm{~ns}$ & $0.36 \mathrm{ab}$ & $0.39 \mathrm{~b}$ & $0.06 \mathrm{~b}$ & $28.80 \mathrm{ab}$ \\
& 150 & $0.78 \mathrm{~ns}$ & $0.24 \mathrm{~b}$ & $0.35 \mathrm{~b}$ & $0.20 \mathrm{ab}$ & $19.50 \mathrm{c}$ \\
\hline SMD & & 0.10 & 0.24 & 0.32 & 0.20 & 19.31 \\
\hline
\end{tabular}


The quantum yield of PSII, as indicated by Fv/Fm, was not affected by any of the salt treatments applied. The $\mathrm{Fv}^{\prime} / \mathrm{Fm}^{\prime}$ values, indicators of the proportion of the absorbed energy that is used in photochemical reactions and $\mathrm{qP}$ values, which are related to the proportion of reaction centers that are open under lighting conditions, were not significantly different between treatments for the tree times analyzed. However, qP showed differences related to time of exposure to stress conditions. Their values decreased by $31 \%$ in $150 \mathrm{mM} \mathrm{NaCl}$ treatment after $240 \mathrm{~h}$ compared to $6 \mathrm{~h}$ of treatment. It demonstrates a greater sensitivity of $\mathrm{qP}$ compared to $\mathrm{Fv}^{\prime} / \mathrm{Fm}^{\prime}$.

Therefore, this damage was only important for high levels of salt in the medium during longterm stress. The non-photochemical quenching has only significant changes after $24 \mathrm{~h}$ between the treatment of $150 \mathrm{mM}$ of $\mathrm{NaCl}$ and control. Although the differences obtained in ETR between control and salt stress treatments occurred only after 24 hours of stress, the tendency of this parameter was to decrease with time under saline conditions.

The capacity of photochemical reactions was evaluated through different indicators related to chlorophyll fluorescence (Table 2).

The Fv/Fm value, indicator of the maximum potential capacity of the efficiency of PS II in darkadapted leaves, was not affected by any salt treatment applied. This indicator does not appear to be affected in some plant species subjected to various kinds of stress according to Delfine et al. (1999). Therefore, Roháček, Soukupová and Barták (2008) suggested that the Fv/Fm ratio should never be the only chlorophyll fluorescence parameter taken as an indicator of the stress status-impact to the plant tissue. Other parameters, related to the steady-state photosynthesis, are necessary to describe the status of the photosynthetic apparatus.

The lower $\mathrm{CO}_{2}$ fixation could provoke an accumulation of ATP, NADPH and excited chlorophyll as the light reactions continue. Among the routes for energy dissipation by nonphotochemical quenching that involves the transfer of absorbed light energy away from electron transport are the heat production and the xanthophyll cycle. The salt stress conditions of our experiment seems to have activated the energy dissipation mechanisms through the qN (Table 2). After $24 \mathrm{~h}$ of higher salinity conditions, the xanthophyll cycle could be functioning in $J$. curcas L. plants.

Our results show that after $24 \mathrm{~h}$ of salt stress, $J$. curcas L. leaves decreased the electron transport rate (ETR). The lower flow of energy and its adequate consumption together with an increase of energy dissipation system were operating to prevent further damage through the $\mathrm{qN}$. A better condition was maintained after $240 \mathrm{~h}$ of stress, with no difference in ETR values between control and both salt stress treatments. It is a presumed recuperation of the photochemistry under this condition.

Additionally, the ETR/qN ratio, taken as an estimate of the use of electrons in other processes not related to the photosynthetic $\mathrm{CO}_{2}$ assimilation, was similar in plants under control, 75 and $150 \mathrm{mM} \mathrm{NaCl}$ at all times of stress. This suggests a balance between the photochemical and biochemistry phases, indicating that salinity did not represent a limitation of light reactions. Therefore, we suggest that leaf photochemistry in $J$. curcas L. is rather resistant to salt stress.

As noted in this study, the contribution of respiratory changes under salt stress seems to be a side effect compared to photosynthetic contribution. Changes in respiratory rates occur in a relatively narrow range compared to the changes in photosynthesis, which reduces the net carbon balance in the plant.

In this study, it was observed that the stomatal density is about five times higher in the abaxial $\left(57 \pm 13\right.$ cells per $\left.\mathrm{mm}^{2}\right)$ than in the adaxial $(11 \pm 2$ cells per $\mathrm{mm}^{2}$ ) surface, and the epidermal cells quantity is 1.5 times higher in the abaxial $(822 \pm 12$ cells per $\left.\mathrm{mm}^{2}\right)$ than in the adaxial $\left(534 \pm 49\right.$ cells per $\left.\mathrm{mm}^{2}\right)$ surface. Additionally, the stomata in the adaxial region of $J$. curcas L. leaves are concentrated in areas close to the leaf veins, while in the abaxial region, they are spread over the entire leaf surface (data not shown)

The number of leaf epidermal cells in $J$. curcas L. leaves did not change due to the saline conditions in the abaxial nor in the adaxial surface (Table 3). The stomatal density did not change in the adaxial surface but rather in the abaxial surface, in which it increased after 24 and $240 \mathrm{~h}$ in 75 and 150 $\mathrm{mM} \mathrm{NaCl}$ treatments (Table 3 ). 
Table 3. Epidermal cell and stomatal density in the abaxial (Ab) and adaxial (Ad) surfaces of leaves of $J$. curcas L. plants growing under saline conditions for 6, 24 and 240 hours. Different letters (in a row) denote significant difference in time of stress for each treatment at both leaf surfaces by Tukey test; $\mathrm{P}<0.05 ; \mathrm{n}=21$, ns: no significant difference.

\begin{tabular}{|c|c|c|c|c|c|}
\hline \multirow{3}{*}{$\begin{array}{l}\text { Treatments } \\
(\mathrm{mM} \mathrm{NaCl})\end{array}$} & \multicolumn{4}{|c|}{ Epidermal cell density $\left({\left.\mathrm{No} \mathrm{mm}^{-2}\right)}^{-2}\right.$} & \multirow[b]{3}{*}{ SMD } \\
\hline & \multirow{2}{*}{ Leaf surface } & \multicolumn{3}{|c|}{ Time of stress (h) } & \\
\hline & & 6 & 24 & 240 & \\
\hline \multirow{2}{*}{0} & $\mathrm{Ab}$ & $822 \pm 12 \mathrm{~ns}$ & $767 \pm 13 \mathrm{~ns}$ & $816 \pm 52 \mathrm{~ns}$ & 78.9 \\
\hline & Ad & $534 \pm 49 \mathrm{~ns}$ & $550 \pm 51 \mathrm{~ns}$ & $540 \pm 54 \mathrm{~ns}$ & 128.7 \\
\hline \multirow{2}{*}{75} & $\mathrm{Ab}$ & $778 \pm 51 \mathrm{~ns}$ & $835 \pm 57 \mathrm{~ns}$ & $750 \pm 49 \mathrm{~ns}$ & 131.5 \\
\hline & Ad & $552 \pm 7 \mathrm{~ns}$ & $575 \pm 8 \mathrm{~ns}$ & $470 \pm 40 \mathrm{~ns}$ & 60.3 \\
\hline \multirow{2}{*}{150} & $\mathrm{Ab}$ & $914 \pm 82 \mathrm{~ns}$ & $869 \pm 78 \mathrm{~ns}$ & $799 \pm 98 \mathrm{~ns}$ & 217.5 \\
\hline & Ad & $596 \pm 14 \mathrm{~ns}$ & $583 \pm 16 \mathrm{~ns}$ & $517 \pm 68 \mathrm{~ns}$ & 104.0 \\
\hline \multicolumn{6}{|c|}{ Stomatal density $\left(\mathrm{No} \mathrm{mm}^{-2}\right)$} \\
\hline \multirow{2}{*}{$\begin{array}{l}\text { Treatments } \\
(\mathrm{mM} \mathrm{NaCl})\end{array}$} & \multirow{2}{*}{ Leaf surface } & \multicolumn{3}{|c|}{ Time of stress (h) } & \\
\hline & & 6 & 24 & 240 & SMD \\
\hline \multirow{2}{*}{0} & $\mathrm{Ab}$ & $55 \pm 13 \mathrm{~ns}$ & $60 \pm 14 \mathrm{~ns}$ & $79 \pm 10 \mathrm{~ns}$ & 31.5 \\
\hline & Ad & $11 \pm 2 \mathrm{~ns}$ & $11 \pm 2 \mathrm{~ns}$ & $12 \pm 2 \mathrm{~ns}$ & 4.2 \\
\hline \multirow{2}{*}{75} & $\mathrm{Ab}$ & $56 \pm 3 \mathrm{~b}$ & $70 \pm 3 \mathrm{a}$ & $69 \pm 7 \mathrm{a}$ & 11.4 \\
\hline & $\mathrm{Ad}$ & $9 \pm 0 \mathrm{~ns}$ & $9 \pm 0 \mathrm{~ns}$ & $15 \pm 5 \mathrm{~ns}$ & 8.6 \\
\hline \multirow{2}{*}{150} & $\mathrm{Ab}$ & $58 \pm 7 \mathrm{~b}$ & $70 \pm 8 a b$ & $79 \pm 8 \mathrm{a}$ & 20.3 \\
\hline & Ad & $12 \pm 3 \mathrm{~ns}$ & $11 \pm 2 \mathrm{~ns}$ & $13 \pm 2 \mathrm{~ns}$ & 6.7 \\
\hline
\end{tabular}

In the abaxial leaf surface it was observed that the $150 \mathrm{mM} \mathrm{NaCl}$ treatment promoted the closure of the stomata at the beginning $(6 \mathrm{~h})$ (Figure 5). After
24 hours and 240 hours of exposure, no significant differences were observed between saline treatments and the control group.

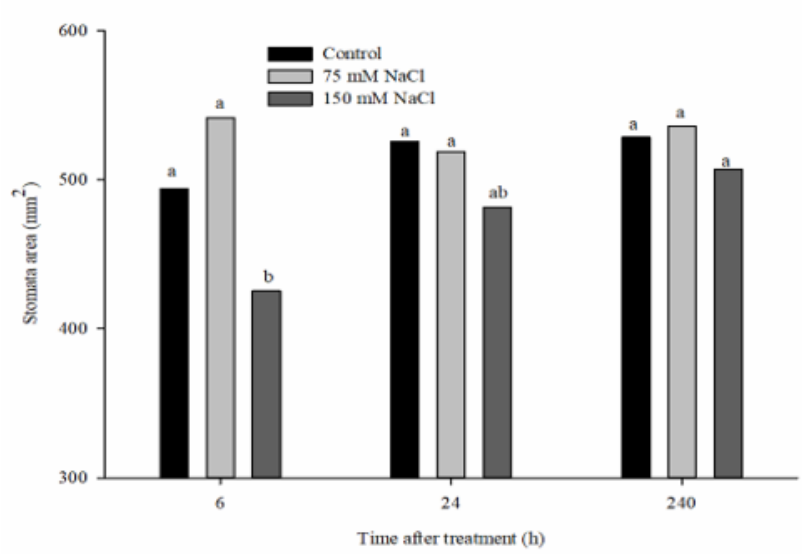

Figure 5. Salinity effect on the stomata area in the abaxial leaf surface of $J$. curcas L. plants at different times under saline treatment $(75$ and $150 \mathrm{mM} \mathrm{NaCl})$. Different letters denote significant difference between samples $(\mathrm{P}<0.05)$ by Tukey test; $\mathrm{n}$ $=18 ; \mathrm{SMD}=63.68$. 
Reduction in the size of the stomata increases stomatal resistance, which limits the excessive water loss by transpiration. $J$. curcas L. plant controls the loss of water through the stomata by closing them during the first 6 hours of stress, but with the longterm salt stress the control is obtained with the modification of stomatal density. The much higher stomatal density indicates that salt stress induces the formation of leaves with an altered anatomy. More stomata in the abaxial surface of the leaf permit a tighter regulation of water loss. In this way, the $J$. curcas L. plant can maintain the water supply to the cells and the RWC even after $240 \mathrm{~h}$ of salt stress.

According to our results, the reduction in photosynthetic rate could not be due to stomatal limitation because there was no stomatal closure in response to salinity (Figure 5). The reduction in photosynthetic rate could be related to other factors as mentioned previously.

\section{Effects of Salinity Stress on SOS and HKT1 Genes}

Information related to salt tolerance of $J$. curcas L. at molecular level is insufficient. We analyzed, in $J$. curcas L. submitted to saline conditions for $6 \mathrm{~h}$, the gene expression pattern of key genes involved in salinity tolerance (Figure 6). SOS1 expression in root was repressed under 75 and 150 $\mathrm{mM}$ of $\mathrm{NaCl}$ while in leaf its expression was not modified. Amounts of mRNA increased for $H K T 1$ gene in root and leaf of plants at $75 \mathrm{mM}$ of $\mathrm{NaCl}$, but decreased at $150 \mathrm{mM}$ of $\mathrm{NaCl}$ in both organs compared to control. Gene expression profile for SOS3 gene was not modified in leaf and root as well as SOS2 in leaf.

\section{Leaf}

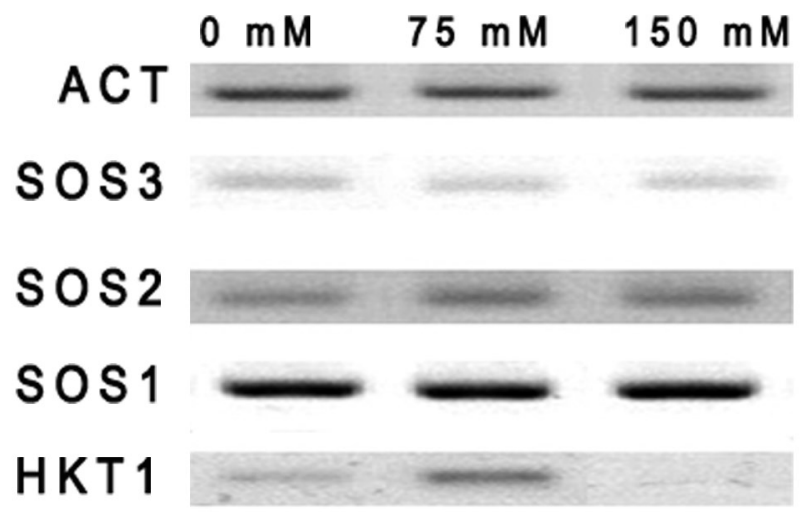

Root

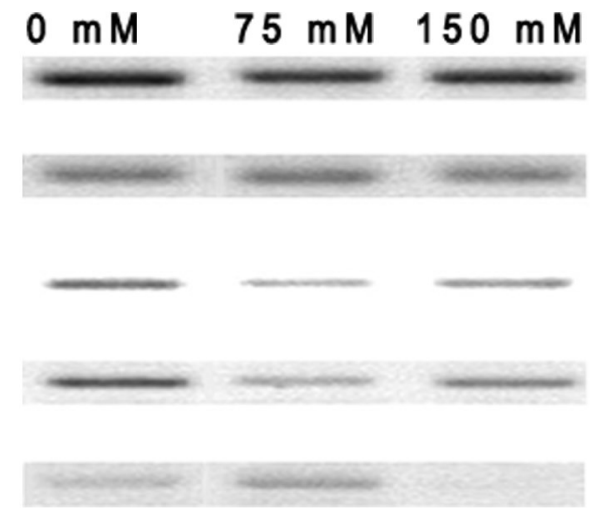

Figure 6. Semi quantitative RT-PCR analysis showing differential gene expression depending on the salt level for HKT1 gene of Jatropha curcas L. The expression of each gene was compared relative to its expression in control gene (ACT). DNA samplings were carried out at 24 and $240 \mathrm{~h}$ after treatments with 0,75 and $150 \mathrm{mM} \mathrm{NaCl}$.

According to Zhang et al. (2014), 1504 and 1115 genes modified their expression in root and leaves, respectively, in $J$. curcas L. under $100 \mathrm{mM}$ of $\mathrm{NaCl}$ treatment, but none of them belong to the SOSs and HKT1 genes. In our work we found that mainly SOS1 and HKT1 modified the expression pattern depending the $\mathrm{NaCl}$ concentration. Up and down regulation of HKT1 at $75 \mathrm{mM}$ and $150 \mathrm{mM}$ respectively indicate the tolerance of the $J$. curcas L. plant to salt stress. At $75 \mathrm{mM}$ of $\mathrm{NaCl}$, the $\mathrm{Na}^{+}$could enter into the cell, as was detected by Díaz-López et al. (2012) using $60 \mathrm{mM}$ of $\mathrm{NaCl}$, and the plant has mechanisms to deal with it. At higher $\mathrm{Na}^{+}$ concentrations in the medium (90-150 mM), there was no increase in the $\mathrm{Na}^{+}$concentration in the root, indicating some efficient mechanism for salt exclusion, as suggested by Díaz-López et al. (2012). Our result supports the idea that the plant activates the mechanism to avoid the entry of $\mathrm{Na}^{+}$, inhibiting the HKT1 transport, detected in our work as less $H K T 1$ transcript, and activating the $\mathrm{Na}^{+}$exclusion, detected in our work as higher SOS1 transcript at 150
$\mathrm{mM}$ than at $75 \mathrm{mM}$ of $\mathrm{NaCl}$ in root.

\section{CONCLUSIONS}

Photosynthesis activity of $J$. curcas L. was not affected by moderate salinity levels of $75 \mathrm{mM}$ $\mathrm{NaCl}$. Additionally, other physiological and morphological traits such as stomatal opening and membrane damage in leaves were not affected by 75 $\mathrm{mM} \mathrm{NaCl}$ nor even by the highest salt level applied $(150 \mathrm{mM} \mathrm{NaCl})$. As a consequence, leaf growth (RLGR and ALGR) was not affected by a salinity of $75 \mathrm{mM} \mathrm{NaCl}$, equivalent to approximately $7 \mathrm{dS} \mathrm{m}^{-1}$. Modified expressions of SOS1 and HKT1 genes, different for 75 and $150 \mathrm{mM}$ of $\mathrm{NaCl}$, indicates that the plant is able to tolerate $\mathrm{Na}^{+}$in the tissue and has efficient mechanism to avoid damage. These results suggest that $J$. curcas $\mathrm{L}$. is an appropriate species to be cultivated in semi-arid regions. 


\section{ACKNOWLEDGEMENTS}

This research was supported by the CAPES/ MES - Brazil-Cuba project (no 141/11. AUXPE no $385 / 2012$ ). We also thank UFRN, UFERSA and Universidad de La Habana for supporting this research project. To Mike Zirkel for helping with the English language.

\section{REFERENCES}

ALLBED, A.; KUMAR, L. Soil salinity mapping and monitoring in arid and semi-arid regions using remote sensing technology: A review. Advances in Remote Sensing, 2: 373-385, 2013.

BATOOL, N.; SHAHZAD, A.; NOSHIN, I. Plants and salt stress. International Journal of Agriculture and Crop Sciences, 7: 582, 2014.

BOYER, J. S. Leaf enlargement and metabolic rates in corn, soybean, and sunflower at various leaf water potentials. Plant Physiology, 46: 233-235, 1970.

BRADFORD, K. J.; HSIAO, T. C. Physiological responses to moderate water stress. In: Lange, O. L.; Nobel, P. S.; Osmond, C. B.; Ziegler, H. (Eds.). Physiological plant ecology II. Springer, Berlin, Heidelberg, 1982. v. 12B, cap. 9, p. 263-324.

BRUGNOLI, E.; BJÖRKMAN, O. Growth of cotton under continuous salinity stress: influence on allocation pattern, stomatal and non-stomatal components of photosynthesis and dissipation of excess light energy. Planta, 187: 335-347, 1992.

CHAVES, M. M.; FLEXAS, J.; PINHEIRO, C. Photosynthesis under drought and salt stress: regulation mechanisms from whole plant to cell. Annals of Botany, 103: 551-560, 2009.

CONNOR, D. J.; JONES, T. R. Response of sunflower to strategies of irrigation II. Morphological and physiological responses to water stress. Field Crops Research, 12: 91-103, 1985.

DELFINE, S. et al. Restrictions to carbon dioxide conductance and photosynthesis in spinach leaves recovering from salt stress. Plant Physiology, 119: 1101-1106, 1999.

DÍAZ-LÓPEZ, L. et al. The tolerance of Jatropha curcas seedlings to $\mathrm{NaCl}$ : An ecophysiological analysis. Plant Physiology and Biochemistry, 54: 34-42, 2012.

GULEN, H.; ERIS, A. Effect of heat stress on peroxidase activity and total protein content in strawberry plants.Plant Science, 166: 739-744, 2004.

HOAGLAND, D. R.; ARNON, D. I. The waterculture method for growing plants without soil.California Agricultural Experiment Station Circular, 347: 1-32, 1950.

HUNT, R. Relative growth rates. In: HUNT, R. (Ed.) Basic Growth Analysis. Springer, Dordrecht, 1990. cap. 3, p. 25-34.

IRIGOYEN, J. J.; EMERICH, D. W.; SANCHEZDIAZ, M. Water stress induced changes in concentrations of proline and total soluble sugars in nodulated alfalfa (Medicago sativa) plants. Physiologia Plantarum, 84: 55-60, 1992.

JIANG, C. et al. Effect of exogenous selenium supply on photosynthesis, $\mathrm{Na}^{+}$accumulation and antioxidative capacity of maize (Zea mays L.) under salinity stress. Scientific reports, 7: 1-14, 2017.

KRAMER, P. J.; BOYER, J. S. Water relations of plants and soils. San Diego, Academic Press, 1995. $495 \mathrm{p}$.

LAWLOR, D. W. Limitation to photosynthesis in water-stressed leaves: stomata vs. metabolism and the role of ATP. Annals of Botany, 89: 871-885, 2002.

MEDERSKI, H. J.; CHEN, L. H.; CURRY, R. B. Effect of leaf water deficit on stomatal and nonstomatal regulation of net carbon dioxide assimilation. Plant Physiology, 55: 589-593, 1975.

MITEVA, T. S.; ZHELEV, N. Z.; POPOVA, L. P. Effect of salinity on the synthesis of Ribulose-1,5bisphosphate Carboxylase/Oxygenase in barley leaves. Journal of Plant Physiology, 140: 46-51, 1992.

MOORE, J. P. et al. Adaptations of higher plant cell walls to water loss: drought vs desiccation. Physiologia Plantarum, 134: 237-245, 2008.

MUNNS, R. Comparative physiology of salt and water stress. Plant, Cell and Environment, 25: 239 $-250,2002$.

PESSARAKLI, M.; HUBER, J. T.; TUCKER, T. C. Dry matter yield, nitrogen absorption, and water uptake by sweet corn under salt stress. Journal of Plant Nutrition, 12: 279-290, 1989.

RAD, M. R. N. et al. Gene action for physiological parameters and use of relative water content (RWC) for selection of tolerant and high yield genotypes in F2 population of wheat. Australian Journal of 
Crop Science, 7: 407, 2013.

RAJ, S.; MOHAN, S. Impact on proline content of Jatropha curcas in fly ash amended soil with respect to heavy metals. International Journal of Pharmacy and Pharmaceutical Sciences, 8: 244247, 2016.

ROHÁČEK, K.; SOUKUPOVÁ J.; BARTÁK M. Chlorophyll fluorescence: A wonderful tool to study plant physiology and plant stress. In: SCHOEFS, B. (Ed.). Plant Cell Compartments. Kerala: Research Signpost, 2008. v. 2, cap. 3, p. 41-104.

SAPETA, H. et al. Drought stress response in Jatropha curcas: growth and physiology. Environmental and Experimental Botany, 85: 7684, 2013.

SEEMANN, J.; SHARKEY T. D. Salinity and nitrogen effects on photosynthesis, Ribulose-1,5bisphosphate carboxylase and metabolite pool sizes in Phaseolus vulgaris L. Plant Physiology, 82: 555560, 1986.

SHIRIVASTAVA, P.; KUMAR, R. Soil salinity: A serious environmental issue and plant growth promoting bacteria as one of the tools for its alleviation. Saudi Journal of Biological Sciences, 22: 123-131, 2015.

SILVA, E. N. et al. Photosynthetic and antioxidant responses of Jatropha curcas plants to heat stress: on the relative sensitivity of shoots and roots. Journal of Plant Growth Regulation, 37: 255-265, 2018.

SLAVIK, B. Methods of studying plant water relations. Heidelberg - Berlin, Springer-Verlag NewYork, 1974. 449 p.

STITT, M.; ZEEMAN, S. C. Starch turnover: pathways, regulation and role in growth. Current Opinion in Plant Biology, 15: 282-292, 2012.

TAKAHASHI, S.; BADGER, M. R. Photoprotection in plants: a new light on photosystem II damage. Trends in Plant Science, 6: 53-60, 2011.

TARDIEU, F.; GRANIER, C.; MULLER, B. Water deficit and growth. Co-ordinating processes without an orchestrator? Current Opinion in Plant Biology, 14: 283-289, 2011.

WANG, Y.; NII, N. Changes in chlorophyll, ribulose bisphosphate carboxylase-oxygenase, glycine betaine content, photosynthesis and transpiration in Amaranthus tricolor leaves during salt stress. The Journal of Horticultural Science and
Biotechnology, 75: 623-627, 2015.

ZHANG, L. et al. Global analysis of gene expression profiles in Physic Nut (L.) seedlings exposed to salt stress. PLOS ONE, 9: e97878, 2014. 